\title{
PENGUJIAN MATERIAL BATU GUNUNG AMONGGEDO SEBAGAI BAHAN LAPIS PONDASI ATAS (BASE COURSE) PADA KONTRUKSI JALAN RAYA
}

\author{
Wirdha Ningsih ${ }^{1}$ \\ Ahmad Syarif Sukri ${ }^{2}$ \\ ${ }^{1}$ Staf Pengajar Sekolah Tinggi Teknologi Mekongga Sulawesi Tenggara \\ ${ }^{2}$ Staf Pengajar Program Studi Teknik Sipil Fakultas Teknik Universitas Halu Oleo Sulawesi Tenggara \\ E-mail: wirdhaningsih@gmail.com
}

\begin{abstract}
Abstrak
Salah satu sumber material bangunan di Sulawesi Tenggara yang cukup potensial dan layak untuk digunakan adalah batu gunung Amangodo, di Kecamatan Pondidaha Kabupaten Konawe. Lokasi tersebut telah lama dimanfaatkan oleh masyarakat sekitarnya untuk keperluan bangunan sipil, sedangkan pemeriksaan mutu agregat khususnya sebagai bahan perkerasan belum pernah dilakukan. Tujuan penelitian ini adalah untuk mengetahui apakah batu gunung Amonggedo memenuhi syarat untuk digunakan sebagai bahan konstruksi lapis pondasi agregat kelas A (Base course) pada konstruksi jalan raya. Metoda yang digunakan dalam penelitian ini adalah pemeriksaan dan pengujian karakteristik agregat yang dilakukan di laboratorium pengujian dan konstruksi Teknik Sipil Fakultas Teknik Universitas Halu Oleo Kendari. Hasil penelitian menunjukan bahwa material Desa Amonggedo Kecamatan Pondidaha layak dan dapat digunakan sebagai bahan lapis pondasi agregat kelas A seperti yang disyaratkan dalam spesifikasi lapis pondasi kelas A buku 3 spesifikasi Bina Marga.
\end{abstract}

Kata Kunci : Material, gunung, agregat, jalan raya, pondasi

\begin{abstract}
The tests on mountain stone materials on the Amonggedo's district as the foundation for material layer in highway construction. One of the sources for building materials in Southeast Sulawesi that considerably potential and deserved to be used is the mountain stone in Amangodo, a district in Pondidaha Konawe Southeast Sulawesi. This area has long been used by the surrounding community for the purposes of civil construction, while the aggregate quality inspection in particular as pavement material has not been done. The purpose of this study is to determine whether the mountain rock of Amonggedo eligible to be used as a construction material for the Aggregate Base Class A (Base course) on highway construction. The method used in this study is the examination and testing of the aggregate characteristics conducted in laboratory of the construction of Civil Engineering of Halu Oleo University Kendari. The results show that the material of Amonggedo is feasible and can be used as the ingredient Aggregate Base Class A as specified in the foundation layer in the specification grade A book 3 of highways.
\end{abstract}

Keywords: Material, mountain, aggregate, highways, foundation

\section{Pendahuluan}

Pembangunan nasional akan baik, jika ditunjang oleh pembangunan prasarana jalan yang memadai sesuai dengan tingkat kebutuhan pembangunan yang dikehendaki. Pembangunan prasarana jalan diarahkan untuk lebih memperlancar arus barang dan jasa serta meningkatkan arus mobilitas ke seluruh wilayah tanah air.
Desa Amonggedo Kecamatan Pondidaha ( lokasi penelitian) merupakan salah satu daerah dengan luasan wilayah yang potensial bagi tambang batu gelondongan. Dengan potensi material yang cukup besar tersebut, maka daerah ini dapat dijadikan sebagai salah satu tambang batu gelondongan, yang dapat dijadikan sebagai batu pecah untuk pekerjaan perkerasan jalan maupun agregat pondasi pada konstruksi jalan raya. 
Tujuan penelitian adalah untuk mengetahui apakah batu di Desa Amonggedo memenuhi syarat untuk digunakan sebagai bahan konstruksi lapis pondasi agregat kelas A (Base Course) pada konstruksi jalan raya.

\section{Tinjauan Pustaka}

ASTM (1974) mendefinisikan batuan sebagai suatu bahan yang terdiri dari mineral padat, berupa massa berukuran besar ataupun fragmen fragmen (Sukirman, 1995). Agregat atau batuan secara umum didefinisikan sebagai deformasi kulit bumi yang keras dan kenyal sebagai bahan yang terdiri dari minera. Berdasarkan besar kecilnya partikel-partikel agregat, maka agregat ini dapat dibedakan atas: agregat kasar, yaitu agregat dengan ukuran partikel lebih besar dari 4,75 $\mathrm{mm}$ menurut ASTM atau lebih besar dari 2 mm menurut AASHTO, agregat halus, yaitu agregat $4,75 \mathrm{~mm}$ menurut ASTM atau $2 \mathrm{~mm}$ dan lebih kecil dari 0,075 mm menurut AASHTO dan abu batu / material filler, yaitu agregat halus yang umumnya lolos saringan nomor 200 (Harold, 2003).

Karakteristik agregat menentukan kemampuannya dalam memikul beban lalu lintas. Agregat dengan sifat dan kwalitas yang baik dibutuhkan untuk lapisan permukaan yang langsung memikul beban lalu lintas dan menyebarkan kelapisan di bawahnya. Dapat tidaknya suatu jenis agregat dapat digunakan lapis pondasi atas pada konstruksi perkerasan lentur ditentukan dari kerasteristik bahan itu sendiri, antara lain: gradasi, berat jenis dan penyerapan agregat, kadar lembung, daya tahan agregat dan bentuk butir dan tekstur permukaan (Anonimous, 1976).

Gradasi agregat diperoleh dari hasil analisa saringan dengan mengunakan 1 set saringan dimana saringan yang paling kasar diletakkan diatas saringan yang paling halus terletak paling bawah. Gradasi agregat dapat dibedakan atas 3 bagian. Gradasi yang pertama adalah seragam ( uniform graded), dimana agregat yang dengan ukuranya yang hampir sama /sejenis atau mengandung agregat halus yang sedikit jumlahnya sehingga tidak dapat mengisi rongga antar agregat. Gradasi yang kedua adalah rapat (danse graded ), yang merupakan campuran agregat kasar dan halus dalam porsi yang seimbang, sehingga dinamakan juga agregat bergradasi baik. Gradasi yang terakhir adalah buruk/jelek (poorly graded), merupakan campuran agregat yang tidak memenuhi 2 kategori sebelumnya. Agregat yang bergradasi buruk umumnya digunakan untuk lapisan perkerasan lentur yaitu gradasi celah (gap graded) yaitu merupakan campuran agregat dengan 1 fraksi hilang atau 1 fraksi sedikit sekali. Gradasi ini sering juga disebut gradasi senjang yang akan menghasilkan lapisan perkerasan yang mutunya terletak antara kedua jenis di atas (Sukirman, 1995).

Berat jenis agregat adalah berbandingan antara berat volume agregat dan berat volume air. Ada tiga jenis pemeriksaan berat jenis yang dapat ditentukan berdasarkan manual PB 2020-76 atau AASHTO85-85 (Anonimous, 1995).

Berat jenis (bulk spesifik grafity) adalah perbandingan antara berat agregat kering dan berat suling yang isinya sama dengan isi agregat dalam keadaan jenuh pada suhu tertentu. Berat jenis kering permukaan jenuh ( SSD) adalah perbandingan antara berat permukaan kering permukaan jenuh dan berat air suling yang isisnya sama dengan isi agregat dalam keadaan jenuh pada suhu tertentu. Berat jenis semu (apparent specific grafity) adalah perbandingan antara berat agregatkering dan berat air suling yang isisnya sama dengan isi agregat dalam keadaan kering dalam suhu tertentu. Penyerapan adalah persentase berat air yang dapat diserap pori terhadap berat agregat kering (Mulyadi, 2010).

\section{Metode Penelitian}

Pengambilan data pada penelitian ini dilakukan pada bulan Juli 2013 di Desa Amangodo, Kecamatan Pondidaha Kabupaten Konawe. Metode pengumpulan data dilakukan dengan cara pemeriksaan dan pengujian karakteristik agregat yang dilakukan di aboratorium pengujian dan konstruksi Teknik Sipil Fakultas Teknik Universitas Halu Oleo Kendari.

\section{Hasil dan Pembahasan}

Pada hasil pemeriksaan berat jenis dan penyerapan agregat kasar (AASHTO T 84-74), pada percobaan I, diperoleh berat badan uji kering oven (BK) sebesar 1140 gram, berat benda uji kering permukaan jenuh (BJ) sebesar 1155 gram, berat benda uji dalam air (BA) 


\section{DINAMIKA Jurnal IImiah Teknik Mesin}

sebesar 705 gram dan berat jenis (BULK ) sebesar 2,53. Berat jenis permukaan jenuh adalah (BJ) 57, berat jenis semu adalah 2,62 dana penyerapan (absorption) sebesar 1,32\%.

Pada percobaan II, berat benda uji kering oven adalah 1150 gram, berat benda uji kering permukaan jenuh (BJ) adalah 1166 gram, berat benda uji dalam air (BA) adalah 712 gram, berat jenis (BULK) adalah 2,53, berat jenis permukaan jenuh 2,57 dan berat jenis semu 2,63. Nilai penyerapan (absorption) yang diperoleh adalah $1,39 \%$.

Tabel 1. Hasil Pemeriksaan Berat Jenis dan Penyerapan Agregat Kasar (AASHTO T 84-74 )

\begin{tabular}{|c|c|c|c|c|}
\hline \multirow[t]{2}{*}{ No } & \multirow[t]{2}{*}{ Uraian } & \multicolumn{3}{|c|}{ Percobaan } \\
\hline & & 1 & II & III \\
\hline 1. & Berat mould (gr) & 4399 & 4399 & 4399 \\
\hline 2. & Berat mould + agregat (gr) & 8880 & 8885 & 8890 \\
\hline 3. & Berat agregat (gr) & 4481 & 4486 & 4491 \\
\hline 4. & Volume mould $(\mathrm{cm} 3)$ & 2826,00 & 2826,00 & 2826,00 \\
\hline 5. & Berat isi $=3 / 4(\mathrm{gr} / \mathrm{cm} 3)$ & 1,59 & 1,59 & 1,59 \\
\hline
\end{tabular}

Pada pemeriksaan kadar air agregat kasar (ASTM C-556-67), pada percobaan I diperoleh berat wadah $\left(\mathrm{W}_{1}\right)$ sebesar 97,12 gram, berat sample sebelum di oven $\left(\mathrm{W}_{2}\right)$ adalah 202,88 gram dan berat sample setelah di oven (W3) adalah 201,38 gram. Dari data sebelumnya, didapatkan kadar air sebesar $0.74 \%$.

Pada percobaan II, diperoleh berat wadah $\left(\mathrm{W}_{1}\right)$ sebesar 76,25 gram, berat sample sebelum di oven $\left(\mathrm{W}_{2}\right)$ sebesar 223,75 gram dan berat sample setelah di oven $\left(\mathrm{W}_{3}\right)$ sebesar 221,75 gram, sehingga didapatkan kadar air sebesar $0.89 \%$. Dari dua percobaan sebelumnya, didapatkan kadar air rata-rata sebesar $0,82 \%$

Pada pemeriksaan kadar lumpur agregat kasar (AASHTO TII-74) diperoleh berat kering sebelum dicuci 196,7 gram dan berat kering setelah dicuci sebesar 194,09gram. Dari data ini didapatkan kadar lumpur sebesar 1,42\%.

Pada pemeriksaan keausan dengan mesin los angeles (abration test) (AASHTO T96-74), diperoleh nilai abrasi sebesar 30,67\%. Pada pemeriksaan batas cair (liquid limits) (AASHTO $\mathrm{T}$ 89-68), hasil yang diperoleh berupa jumlah pukulan dan kadar air yang bersangkutan, kemudian digambar dalam bentuk grafik. Jumlah pukulan sebagai sumbu mendatar dengan skala logaritma serta besarnya kadar air sebagai sumbu tegak dengan skala biasa.
Nilai percobaan batas cair dan batas plastis dihitung nilai indeks plastisitas (IP) dengan mengunakan rumus (Anonimous , 2003 dan Harold, 2003)

IP $\quad=\mathrm{LL}-\mathrm{PL}$

Dimana, LL adalah Liquid limits (batas cair) dan $\mathrm{L}$ adalah plastis limits (batas plastis). Diketahui bahwa nilai batas cair (LL) sebesar 24,2 dan batas plastis sebesar 19,6, maka indeks plastisitasnya adalah 4,6 .

Dari hasil pemeriksaan kepadatan diperoleh nilai kepadatan kering maksimum (yd maks ) sebesar 2,23 gram $/ \mathrm{cm} 3$, sedangkan kadang air optimum sebesar $5,57 \%$

Dari pemeriksaan CBR laboratorium (AASHTO $\mathrm{T}$ 180) pada CBR 5 lapis 10 tumbukan diperoleh berat isi kering rata-rata sebesar 1,89\% dan CBR rata-rata sebesar $35,92 \%$. Pada CBR 5 lapis 25 tumbukan diperoleh berat isi kering rata-rata sebesar $1,925 \%$ dan CBR rata-rata sebesar 60,06\%. Pada CBR 5 lapis 65 tumbukan diperoleh berat isi kering rata-rata sebesar 2,16\% dan CBR rata-rata sebesar $84,15 \%$.

Dari hasil pemeriksaan rongga dalam agregat mineral pada kepadatan maksimum didapatkan berat volume/isi agregat dalam keadaan padat sebesar 1,63, berat isi (d) maksimum sebesar 
2,23. Dari data ini, didapatkan nilai rongga sebesar $26.9 \%$.

Pada pemeriksaaan abrasi agregat kasar, hasil yang diperoleh pada percobaan keausan dengan mengunakan mesin los angeles dengan cara menunjukkan bahwa keausan rata-rata dari dua kali percobaan adalah sebesar 30,67\%. Pada penetuan indeks plastisitas, dari hasil nilai percobaan batas cair dan batas plastis maka besarnya nilai indeks plastisitas adalah 4,5\% (persyaratan dalam spesifikasi pondasi klas A adalah 0-6\%). Dari hasil nilai pemeriksaan batas cair diperoleh nilai 24,2 (sedangkan persyaratan dan spesifikasi lapis pondasi atas adalah $0-25 \%$ ). Berdasarkan hasil yang diperoleh dari pemeriksaan kepadatan standar menunjukkan bahwa kepadatan kering maksimum yang diperoleh adalah mencapai 2,23gr/cm3 dengan kadar air yang dibutuhkan sebesar 5,57\%. Kepadatan yang dicapai pada $95 \%$ kepadatan kering maksimum sebesar 2,12gr/cm3.

Hasil lain yang diperoleh menunjukkan bahwa CBR yang dicapai pada kepadatan kering maksimum mencapai 87,50\%. Hasil ini memenuhi syarat dalam spesifikasi lapis pondasi agregat klas A yaitu minimal $80 \%$. Dari hasil rongga dalam agregat mineral pada kepadatan maksimum diperoleh nilai sebesar 26,9\%, sedangkan persyaratan dalam spesifikasi adalah minimum $14 \%$ untuk klas A. Hal ini juga menunjukkan bahwa rongga dalam agregat mineral pada kepadatan maksimum material tersebut memenuhi spesifikasi yang ada.

\section{Kesimpulan}

Adapun kesimpulan pada penelitian ini adalah bahwa material asal Desa Amonggedo Kecamatan Pondidaha dapat layak dan dapat digunakan sebagai bahan lapis pondasi agregat klas A seperti yang diisyaratkan dalam spesifikasi lapis pondasi klas A buku 3 spesifikasi Bina Marga. Selain itu, material asal Desa Amonggedo dapat memenuhi kebutuhan gradasi lapis pondasi agregat klas A seperti yang diisyaratkan dalam spesifikasi lapis pondasi klas A buku 3 spesifikasi Bina Marga.

Hasil pemeriksaan abrasi (keausan) batu Desa Amonggedo adalah sebesar $30,67 \%$, sedangkan persyaratan abrasi untuk material Base A sebesar $0-40 \%$. Hal ini menunjukan bahwa batu gunung
Desa Amonggedo memenuhi persyaratan keausan (abrasi) agregat Base A.

Selain itu, hasil pemeriksaan batas cair sebesar $24,2 \%$, sedangkan persyaratan batas cair untuk material Base A sebesar 0-25\%. Hal ini juga menunjukan bahwa batu Desa Amonggedo memenuhi persyaratan batas cair agregat Base A.

Hasil pemeriksaan indeks plastisitas sebesar $4,60 \%$, sedangkan persyaratan indeks plastisitas untuk material Base A sebesar 0-6\%. Hal ini menunjukan bahwa Desa Amonggedo memenuhi persyartan indeks plastisitas agregat Base A.

Hasil pemeriksaan CBR pada kepadatan kering maksimum adalah sebesar 87,50 sedangkan persyaratan CBR pada kepadatan kering maksimum pada material Base $\mathrm{A}$ adalah minimum 87. Hal ini menunjukan bahwa batu Desa Amonggedo memenuhi persyaratan CBR pada kepadatan kering maksimum agregat Base A.

Hasil pemeriksaan rongga dalam agregat mineral pada kepadatan maksimum adalah sebesar $26,9 \%$, sedangkan persyaratan rongga dalam agregat mineral pada kepadatan maksimum untuk material Base A adalah minimum 14\%. Hal ini menunjukan bahwa batu Desa Amonggedo memenuhi persyaratan rongga dalam agregat mineral pada kepadatan maksimum agregat Base A.

\section{Daftar Pustaka}

Anonimous.1976."Manual Pemeriksaan Badan Jalan No. O1/MN/BM/1976" Departmen Pekerjaan Umum DirektoratJenderal Bina Marga.

Anonimous.1995."Proyek Peningkatan Jalan, Buku 3 Spesifikasi Jalan". Departmen Pekerjaan Umum Direktorat Bina Marga.

Anonimous.2003."Laporan Praktikum Uji Bahan" Universitas Haluoleo, Kendari.

Harold N. Atkins, PE.2003" Highway Materials, Soils, and Concretes Four Edition". Pearson Education Inc. Upper Saddle River, New Jersey 07458.

Mulyadi S, Elvis, Apriono I, "Uji Isolator Panas Papan Sekam dengan Variasi Ukuran Partikel dan Kepadatan” Jurusan Fisika, 
Universitas Andalas Padang dan Jurusan Teknik Mesin Politeknik Negeri Padang. 2010.

Silvia Sukirman. 1995, "Perkerasan Lentur Jalan Raya", Nova Bandung.1995 
DINAMIKA Jurnal Ilmiah Teknik Mesin 